Article

\title{
A Study on Estimation Equation for Damage and Recovery Costs Considering Human Losses Focused on Natural Disasters in the Republic of Korea
}

\author{
Young Seok Song $\mathbb{D}^{\mathbb{D}}$ and Moo Jong Park* ${ }^{\mathbb{D}}$ \\ Department of Construction Engineering, Hanseo University, Seosan-si 31962, Korea; kind711@hanmail.net \\ * Correspondence: mjpark@hanseo.ac.kr; Tel.: +82-41-660-1051
}

Received: 24 July 2018; Accepted: 28 August 2018; Published: 31 August 2018

check for updates

\begin{abstract}
In this study, we conduct an estimation study of the damage costs, recovery costs, and human losses in the case of natural disasters in the Republic of Korea. This research method analyzed human losses, damage costs, and recovery costs caused by natural disasters that swept across the Republic of Korea over the past 16 years, from 2000 to 2015, including extreme wind, heavy snowfall, typhoon, wind wave, and heavy rainfall. Damage status and trend of occurrence were reviewed for each year's human losses, damage costs, and recovery costs. We propose a calculating equation of the linear regression equation that estimates damage costs and recovery costs considering human losses. The correlation coefficient was 0.898 for the estimation of human losses and damage costs, and 0.889 for the estimation of human losses and recovery costs. In addition, the correlation of both equations was found to be $166 \%$ of damage costs when calculating recovery costs. The results of this study can be used as descriptive statistical data to estimate damage costs and recovery costs according to human losses in case of natural disasters.
\end{abstract}

Keywords: natural disaster; human losses; damage costs; recovery costs; disaster damage

\section{Introduction}

When natural disasters strike, they generate human losses and property damage, both in cases of ordinary meteorological phenomena including rain, snow, and wind, and massive climate phenomena such as typhoon, heavy rainfall, heavy wind, and heavy snowfall due to energy imbalances caused by the Earth's rotation. The frequency of occurrences of localized rainfall and massive typhoons has increased due to recent climate change as well as the rise of inland/ocean temperatures and sea level due to damages aggravated by global warming [1]. In addition, climate change increases the frequency of natural disasters and their intensity due to the increased emission of greenhouse gases $[2,3]$. Although heavy rainfall accounts for most damages associated with natural disasters in the world, a variety of damages are specific to the geographical and climate characteristics of certain nations, such as those caused by typhoon, hurricane, wildfire, and earthquake [4-7].

Studies have been performed in various fields investigating damage costs in terms of economic, social damage, and disaster recovery caused by different types of natural disasters. Many studies have proposed not only an equation that calculates the direct damage costs caused by many types of natural disasters such as typhoon, heavy snowfall, extreme wind, and heavy rainfalls, but an equation that also considers the economic effects caused by abnormal climate due to climate change [8-15]. In addition, it can predict human losses by considering social factors and economic factors, such as days of school classes and the size of governmental budgets as well as damage costs per GDP (Gross Domestic Product), by comparing damages from natural disasters with estimates and analyzed results by constructing a database encompassing hurricane, earthquake, flood damages, and disaster 
recovery [9,16-18]. The estimated equation of damage costs from natural disasters varies according to associations with region, disaster, and economy, most of which estimate the damage costs of a single natural disaster. Thus, it is difficult to calculate comprehensive damage costs generated by natural disasters and apply the results to disaster management.

Insurance companies have conducted studies on the level of national development and damage size for calculating damages to compensate for in the cases of natural disasters. Compensation is based on damage data on natural disasters obtained from studies conducted by insurance companies. In Germany, an equation on wind was developed and applied, while the United States developed and applied an equation on the size and damage of wind and extreme wind [19-23]. In accordance with the developed equation, high-risk regions affected by natural disasters are not likely to be sufficiently rewarded after the potential effects of certain disasters, as disaster compensations are less there than in ordinary regions $[24,25]$. An equation on damage costs constructed by insurance companies only considers damage costs and the size of disasters according to the types of disasters. There has been no research toward the comparison and verification of this equation.

This study examined the effects of damages caused by natural disasters, recovery, and reduction according to economic differences [26-28]. Damages from natural disasters are reduced systematically according to political and economic factors. This study analyzed the percentage of human losses due to human losses and economic factors [8,29-35]. In the United States, national GDP and damage costs from natural disasters have both recently increased by nearly $2 \%$. The U.S. government proposed to alleviate disasters by installing reduction facilities as disaster-rich regions face more disaster damages than ordinary regions $[4,17,33,36-39]$.

Declarations of emergency or requests for international support are allowed if more than 10 people are dead, more than 100 people are injured, or if damage costs exceed $\$ 86$ million when a natural disaster occurs [40]. Disaster management to prepare for natural disasters analyzed the benefits of disaster management costs and damages costs for floods, droughts, and earthquakes [41-44]. Insurance companies have proposed improved modeling through parameters that assess the disaster risk management of the home owner [45-47]. In addition, we evaluated vulnerable areas for hurricanes, storms, tidal waves, and strong winds in coastal areas and developed a damage calculation equation [48-50]. There have been studies on the damage caused by and the reduction of effects on natural disaster damages in accordance with national economic differences, but no studies have been carried out on recovery costs generated by this damage.

In this study, we will investigate the damage status from 2000 to 2015 in the Republic of Korea and develop an estimation equation of damage costs, and recovery costs considering human losses. In this study, natural disasters are defined as acts associated with disasters in the Republic of Korea, and the number of natural disasters per years as well as the current status of damage caused by disasters is also investigated. In addition, it analyzes the current status of damages on human losses, damage costs, and recovery costs according to disasters as well as the number of disasters per year and the current status of damages from natural disasters in the Republic of Korea. It also intends to calculate an estimation equation of damage costs and recovery costs on human losses in natural disasters over the past 16 years and to review the association between damage costs and recovery costs.

\section{Study Area}

\subsection{Classification of Natural Disasters in the Republic of Korea}

In the Republic of Korea, as the Ministry of Public Safety and Security is transferred to the Ministry of the Interior and Safety in July 2017, a central disaster and safety countermeasures headquarters was installed, and disaster management tasks were charged to the safety policy office, the disaster management office, and the Bureau of emergency preparation (Figure 1). When natural disasters occur, the central disaster and safety countermeasures headquarters take responsive measures by using the comprehensive disaster management system. 


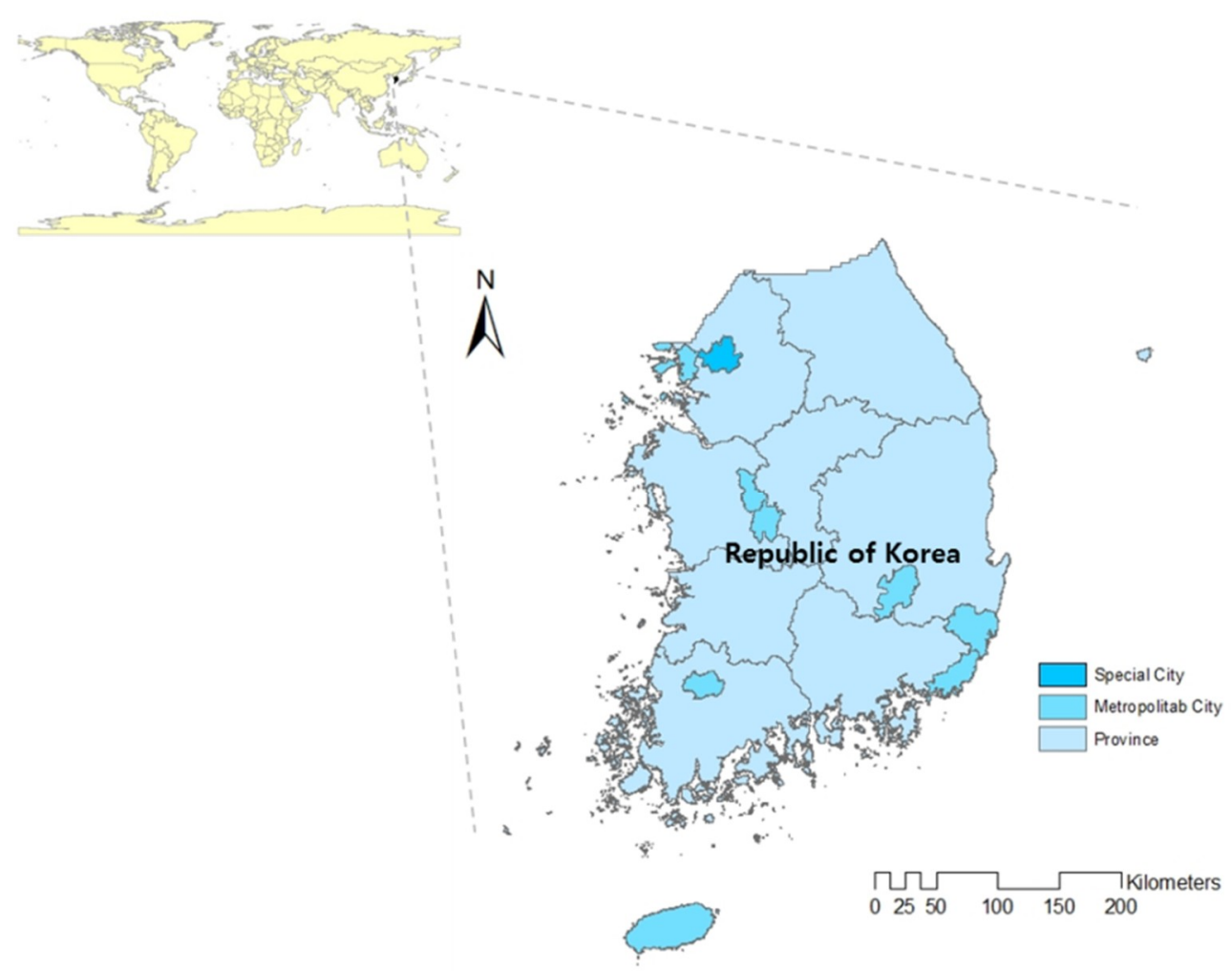

Figure 1. Study Area.

The Framework Act on the management of disasters and safety was enacted for disaster management in the Republic of Korea. It stipulates required details on disaster and safety management as well as prevention, preparation, response, and recovery in the case of disasters. In this act, "natural disasters" refers to catastrophes caused by natural phenomena such as typhoon, flood, heavy rainfall, extreme wind, wind wave, tsunami, heavy snowfall, thunder, drought, earthquake, yellow sand, massive tide, tide, volcanic activity, collision, and clash with natural objects in the universe including asteroids and meteors, and so on. Accordingly, natural disasters in the Republic of Korea are defined as all phenomena that could potentially damage life, body, property of the people, and nation.

The Ministry of the Interior and Safety investigates the status of damage from natural disasters in the Republic of Korea every year and subsequently publishes the Disaster Year Book. This document presents each year's status of damages from extreme wind, heavy snowfall, typhoon, wind wave, and heavy rainfall among the many natural disasters that occurred as defined in the Framework Act on the management of disasters and safety in the Republic of Korea. The local governments of the Republic of Korea investigate the damage caused by natural disasters every year and submit them to the Ministry of the Interior and Safety. The Ministry of the Interior and Safety uses statistical data of each local government to statistically present the damage situation of the national natural disaster. Current information on comprehensive damages such as human losses, damage costs, and recovery costs can be seen on annual natural disasters among types of disasters, metropolitan areas, city and counties, and basin.

\subsection{Current Status of Natural Disasters}

The most frequent natural disasters in the Republic of Korea were summarized for the purpose of identifying the characteristics of the number of natural disasters by year on extreme wind, heavy snowfall, typhoon, wind wave, and heavy rainfall defined in the Disaster Year Book (Table 1). 
Two hundred forty-two natural disasters swept across the nation from 2000 to 2015, which indicates 15 annual cases on average.

The top three years for the number of many natural disasters that occurred over the past 16 years were 2013 (28 times), 2014 (24 times), and both 2010 and 2012 (22 times). On the other hand, the lowest three years were 2002 (four times), 2000 (five times), and 2001 (eight times). In regard to the annual occurrence of natural disasters, heavy rainfall, typhoon, and heavy snowfall continued annually from 2000 to 2015, and extreme wind and wind wave occurred for many years, starting from 2005 [51-66].

Table 1. Number of Natural Disasters in the Republic of Korea According to Year and Disaster (2000 2015) [51-66].

\begin{tabular}{ccccccc}
\hline \multicolumn{7}{c}{ (Unit: Number of Disasters) } \\
\hline Year & Extreme Wind & Heavy Snowfall & Typhoon & Wind Wave & Heavy Rainfall & Sum \\
\hline 2000 & 0 & 0 & 1 & 0 & 4 & 5 \\
2001 & 0 & 2 & 0 & 0 & 6 & 8 \\
2002 & 0 & 0 & 2 & 0 & 2 & 4 \\
2003 & 0 & 0 & 2 & 0 & 8 & 10 \\
2004 & 0 & 3 & 3 & 0 & 5 & 11 \\
2005 & 2 & 6 & 1 & 0 & 9 & 18 \\
2006 & 3 & 2 & 2 & 2 & 7 & 16 \\
2007 & 2 & 1 & 2 & 2 & 7 & 14 \\
2008 & 3 & 5 & 1 & 0 & 3 & 12 \\
2009 & 3 & 3 & 0 & 6 & 6 & 18 \\
2010 & 1 & 5 & 3 & 6 & 7 & 22 \\
2011 & 0 & 4 & 3 & 1 & 11 & 13 \\
2012 & 4 & 5 & 1 & 1 & 18 & 22 \\
2013 & 3 & 4 & 3 & 0 & 15 & 28 \\
2014 & 1 & 2 & 1 & 1 & 7 & 23 \\
2015 & 7 & 47 & 26 & 19 & 121 & 242 \\
Sum & 29 & 3 & 2 & 1 & 8 & 15 \\
Average & 2 & 0 & 0 & 0 & 2 & 4 \\
Min & 0 & 6 & 3 & 6 & 18 & 28 \\
Max & 7 & & & & & 7 \\
\hline
\end{tabular}

Observing the pattern of natural disasters that occurred from 2000 to 2015 in the Republic of Korea, fewer than 10 occurred almost every year before 2005, fewer than 20 nearly every year between 2006 and 2010, and more than 20 natural disasters occurred every year since 2010 (Figure 2a). Regarding the number of natural disasters, 121 heavy rainfalls occurred with an average of eight annually, 27 heavy snowfalls occurred with an average of approximately three annually in average, 29 extreme winds occurred with an average of nearly two annually, 26 typhoons occurred with an average of two annually, and 12 wind waves occurred with an average of almost one annually (Figure 2b).

Since the 2000s, the numbers of natural disasters have progressively increased, and the rise and fall of the occurrence of natural disasters repeated in near five-year cycles. Observing the one-dimensional regression line according to the occurrence of natural disasters, nearly five natural disasters happened on average in the early 2000s, while this value multiplied five times to nearly 25 times in 2015 . The rise in natural disasters is assumed to have resulted from the increasing numbers of natural disasters caused by rising temperature according to the recent climate change models as well as a rise in localized rainfalls. 


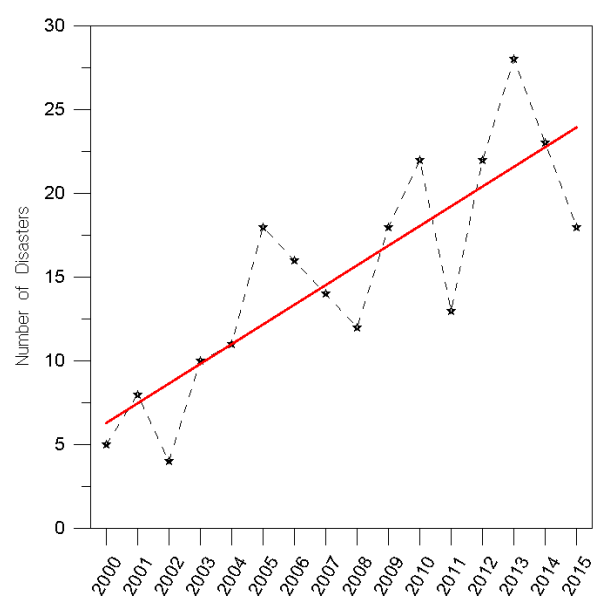

(a)

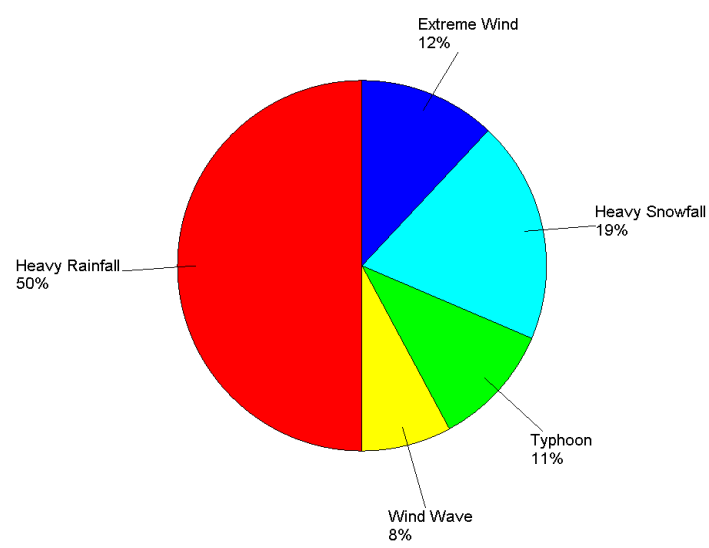

(b)

Figure 2. Current status of natural disasters in the Republic of Korea (2000 2015): (a) Patterns of occurrences of natural disasters by year; (b) Current status of occurrences of disasters according to the type of natural disasters.

\section{Physical and Fiscal Geography of the Study Area}

\subsection{Human Losses According to Natural Disasters}

Human losses from natural disasters in the Republic of Korea continued to occur from 2000 to 2014 , and no human losses occurred in 2015, despite the increase in the number of natural disasters. Natural disasters triggered 833 human losses over the last 16 years. In terms of major damages, 270 people were lost in 2002 and 240 people were lost in 2003, which generated more than 100 human losses in general (Figure 3a).

The relationship between the number of natural disasters and human losses was divided into three sections, from 2000 to 2004, from 2005 to 2009 and from 2010 to 2015. As moving toward 2015, human losses caused by natural disaster dropped in spite of an increasing number of natural disasters. In addition, the range of human losses for natural disasters was 14 to 270 people from 2000 to 2004 , 11 to 52 people from 2005 to 2009, and 0 to 78 people from 2010 to 2015 gradually (Figure 3b).

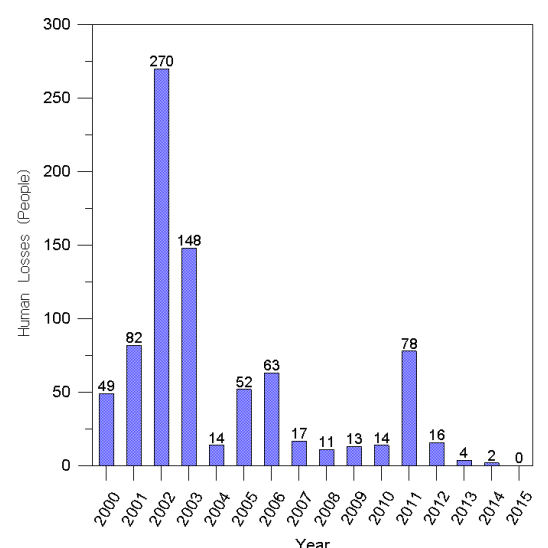

(a)

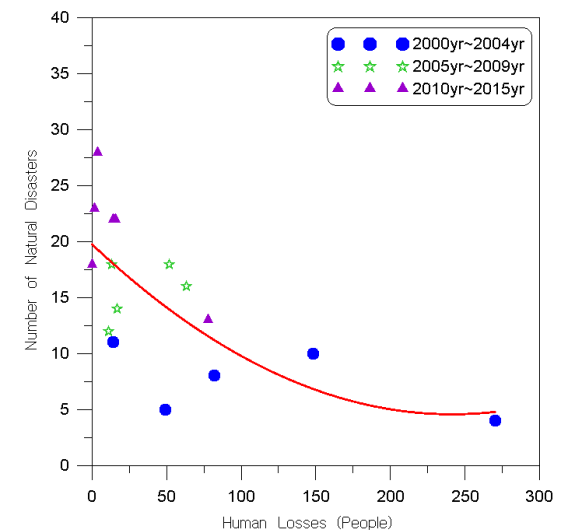

(b)

Figure 3. Current status of human losses from natural disasters in the Republic of Korea (2000-2015): (a) Human losses from natural disasters by year; (b) Relationship of human losses on the number of natural disasters by years. 
Eight hundred thirty-three human losses occurred from 2000 to 2015, and the percentage of human losses by year showed a rate of more than $50 \%$ in 2002 and 2003, 6\%-10\% in 2000, 2001, 2005, 2006, and 2011, and less than 5\% in 2004, 2007, 2008, 2009, 2010, 2012, 2013, 2014, and 2015 (Table 2). Regarding human losses according to natural disasters, typhoon accounted for nearly $52 \%$, amounting to 435 , heavy rainfall accounted for nearly $44 \%$, amounting to 368 , heavy snowfall accounted for nearly $2 \%$, amounting to 12 , and extreme wind accounted for about $1 \%$, amounting to 12 , which showed that typhoon and heavy rainfall triggered the most human losses. The natural disaster caused an average of 10 to 20 Human Losses since 2003. In 2002, 2003, 2005, 2006, and 2011, a large number of human losses occurred every three to five years.

Human damages caused by typhoon were 380 people accounting for nearly $87 \%$ among entire human losses in 2002 and 2003 from two to 23 people in 2000, 2004, 2005, 2007, 2010, 2011, and 2012, and every year except for 2001, 2006, 2008, 2009, 2013, 2014, and 2015 occurred. The human damages caused by heavy rainfall were 265 people, accounting for nearly $72 \%$ of all human losses in 2000 , 2001, 2006, and 2011, from two to 23 people in 2003, 2004, 2005, 2008, 2009, 2010, 2012, 2013, and 2014, and at least one every year except for 2007 and 2015. Human losses caused by extreme wind and heavy snowfall largely occurred in 2005 compared to the other years. There were no human loss cases identified caused by wind waves.

Table 2. Human Losses from Natural Disasters by Year and Disaster in the Republic of Korea (2000 2015) [51-66].

\begin{tabular}{|c|c|c|c|c|c|c|c|}
\hline \multicolumn{8}{|c|}{ (Unit: People) } \\
\hline Year & Extreme Wind & Heavy Snowfall & Typhoon & Wind Wave & Heavy Rainfall & Sum & Ration (\%) \\
\hline 2000 & 0 & 0 & 2 & 0 & 47 & 49 & 6 \\
\hline 2001 & 0 & 4 & 0 & 0 & 78 & 82 & 10 \\
\hline 2002 & 0 & 0 & 247 & 0 & 23 & 270 & 32 \\
\hline 2003 & 0 & 0 & 133 & 0 & 15 & 148 & 18 \\
\hline 2004 & 0 & 0 & 9 & 0 & 5 & 14 & 2 \\
\hline 2005 & 11 & 14 & 6 & 0 & 21 & 52 & 6 \\
\hline 2006 & 0 & 0 & 0 & 0 & 63 & 63 & 8 \\
\hline 2007 & 1 & 0 & 16 & 0 & 0 & 17 & 2 \\
\hline 2008 & 0 & 0 & 0 & 0 & 11 & 11 & 1 \\
\hline 2009 & 0 & 0 & 0 & 0 & 13 & 13 & 2 \\
\hline 2010 & 0 & 0 & 7 & 0 & 7 & 14 & 2 \\
\hline 2011 & 0 & 0 & 1 & 0 & 77 & 78 & 9 \\
\hline 2012 & 0 & 0 & 14 & 0 & 2 & 16 & 2 \\
\hline 2013 & 0 & 0 & 0 & 0 & 4 & 4 & 0 \\
\hline 2014 & 0 & 0 & 0 & 0 & 2 & 2 & 0 \\
\hline 2015 & 0 & 0 & 0 & 0 & 0 & 0 & 0 \\
\hline Sum & 12 & 18 & 435 & 0 & 368 & 833 & 100 \\
\hline Average & 1 & 1 & 27 & 0 & 23 & 52 & 6 \\
\hline Min & 0 & 0 & 0 & 0 & 0 & 0 & 0 \\
\hline Max & 11 & 14 & 247 & 0 & 78 & 270 & 32 \\
\hline
\end{tabular}

\subsection{Damage Costs from Natural Disasters}

Damage costs ranging from 32 billion-6.115 trillion won were generated in the Republic of Korea due to natural disasters from 2000 to 2015. Natural disasters triggered damage costs of 19.947 trillion won in total over the past 16 years. In terms of major damages, 6.115 trillion won were generated in 2002 and 4.408 trillion won were generated in 2003 (Figure 4a).

The relationship between number of natural disasters and damage costs was divided into three sections, from 2000 to 2004, from 2005 to 2009 and from 2010 to 2015. The amount of damages caused by natural disasters by year decreased to the minimum and maximum range of damages by three sections even though the number of natural disasters increased by 2015. In addition, the range of damage costs for natural disasters was 645-6115 billion won from 2000 to 2004, 64-1943 billion won from 2005 to 2009, and 32-1089 billion won from 2010 to 2015 (Figure 4b). 


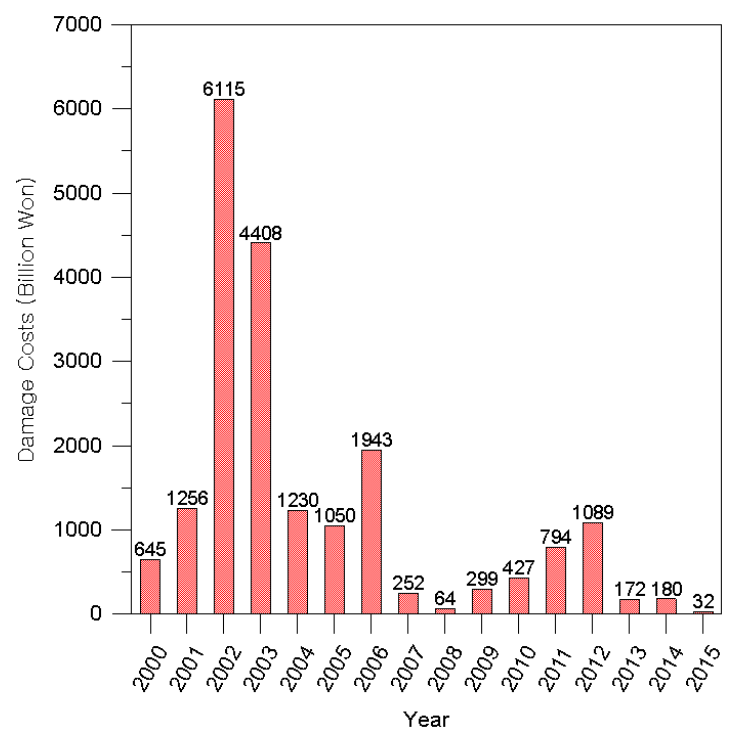

(a)

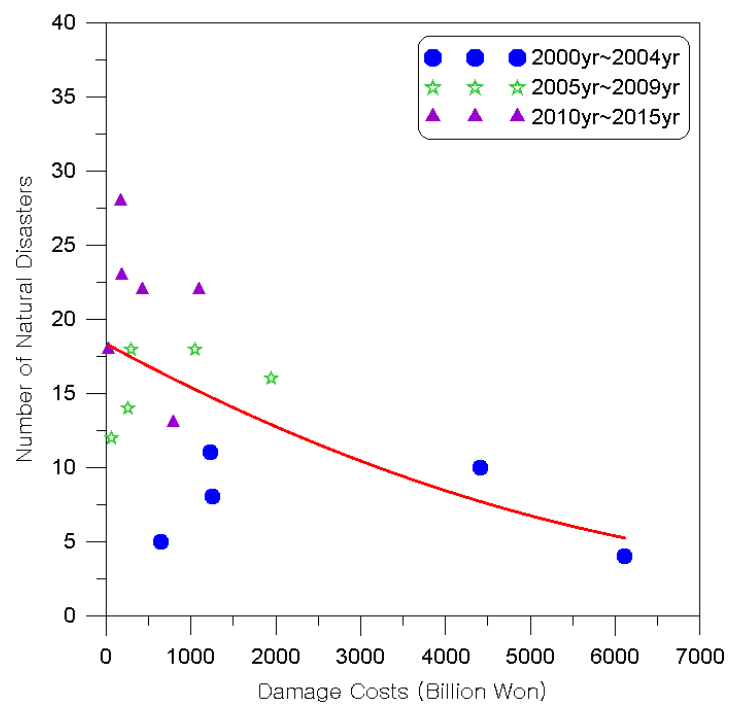

(b)

Figure 4. Current status of damage costs from natural disasters in the Republic of Korea (2000-2015): (a) Damage costs from natural disasters by year; (b) Relationship of damage costs on the number of natural disasters by year.

The total damage costs from 2000 to 2015 amounted to 19.947 trillion won, and the percentages of recovery costs by year were more than $20 \%$ in 2002 and 2003, and 5\%-10\% in 2001, 2004, 2005, 2006, 2011, and 2012. In addition, less than $5 \%$ was found in 2000, 2007, 2008, 2009, 2011, 2013, 2014, and 2015 (Table 3). In regard to damage costs caused by the type of natural disaster, typhoon accounted for $58 \%$, amounting to 11.63 trillion won, heavy rainfall accounted for nearly $30 \%$, amounting to 5.941 trillion won, heavy snowfall accounted for nearly $11 \%$, amounting to 2.241 trillion won, extreme wind accounted for approximately $1 \%$, amounting to 61 billion won, and wind wave accounted for nearly $1 \%$, amounting to 71 billion won. The annual damage costs caused by natural disasters occur in the form of an M-shaped increase and decrease with a period of about five years.

Table 3. Damage costs from natural disasters by year and disaster in the Republic of Korea (2000-2015) [51-66].

\begin{tabular}{|c|c|c|c|c|c|c|c|}
\hline \multicolumn{8}{|c|}{ (Unit: Billion Bon) } \\
\hline Year & Extreme Wind & Heavy Snowfall & Typhoon & Wind Wave & Heavy Rainfall & Sum & Ration (\%) \\
\hline 2000 & 0 & 0 & 146 & 0 & 499 & 645 & 3 \\
\hline 2002 & 0 & 0 & 5186 & 0 & 930 & 6115 & 31 \\
\hline 2003 & 0 & 0 & 4233 & 0 & 175 & 4408 & 22 \\
\hline 2004 & 0 & 674 & 342 & 0 & 215 & 1231 & 6 \\
\hline 2007 & 7 & 7 & 161 & 33 & 44 & 252 & 1 \\
\hline 2008 & 1 & 4 & 1 & 0 & 58 & 64 & 0 \\
\hline 2009 & 7 & 13 & 0 & 24 & 255 & 299 & 1 \\
\hline 2010 & 0 & 66 & 173 & 7 & 181 & 427 & 2 \\
\hline 2011 & 0 & 48 & 218 & 0 & 528 & 794 & 4 \\
\hline Sum & 61 & 2241 & 11,634 & 71 & 5941 & 19,947 & 100 \\
\hline Average & 4 & 140 & 727 & 4 & 371 & 1247 & 6 \\
\hline Min & 0 & 0 & 0 & 0 & 1 & 32 & 0 \\
\hline Max & 27 & 796 & 5186 & 33 & 1906 & 6115 & 31 \\
\hline
\end{tabular}


The amount of damages caused by typhoons was 5186 billion won in 2002, 4233 billion won in 2004, and 1004 billion won in 2012, resulting in about 90\% of the damage, and 1-342 billion won in $2004,2005,2006,2007,2008,2010,2011,2013,2014$, and 2015. Damage costs caused by heavy rainfall accounted for nearly $48 \%$, amounting to 2.836 trillion won, in 2002 and 2006, 215-499 billion won were generated in 2000, 2001, 2004, and 2005, 142-181 billion won in 2003, 2010, 2013, and 2014, and somewhere from 1 billion won to 58 billion won were generated in 2007, 2008, 2012, and 2015. Damage costs caused by heavy snowfall accounted for nearly $90 \%$, amounting to 2.02 trillion won of total damage costs in 2001, 2004, and 2005, and from 4 billion won to 66 billion won were generated from 2006 to 2015 . Damage costs caused by extreme wind accounted for nearly $94 \%$, amounting to 57 billion won, in 2007 and 2009, and somewhere from 6 billion won to 7 billion won were generated in 2010 . Damage costs caused by wind waves accounted for nearly $67 \%$, amounting to 41 billion won of total damage costs in 2006 and 2012, from 4 billion won to 7 billion won in 2007, 2009, and 2015, and less than 1 billion won were generated in 2008 and 2013.

\subsection{Recovery Costs from Natural Disasters}

Annually, somewhere from 38 billion won to 9.049 trillion won were generated from 2000 to 2015 in terms of recovery costs affected by natural disasters in the Republic of Korea. Natural disasters generated damage costs of 33.134 trillion won. In terms of major damages, 9.049 trillion won occurred in 2002 and 6.740 trillion won were generated in 2003 (Figure 5a).

The relationship between the number of natural disasters and recovery costs was divided into three sections: from 2000 to 2004, from 2005 to 2009, and from 2010 to 2015. Recovery costs caused by natural disasters by year decreased to the minimum and maximum range of damages by three sections even though the number of natural disasters increased by 2015. In addition, the range of recovery costs for natural disasters was 1533-9049 billion won from 2000 to 2004, 147-3651 billion won from 2005 to 2009, and 38-2053 billion won from 2010 to 2015 (Figure 5b).

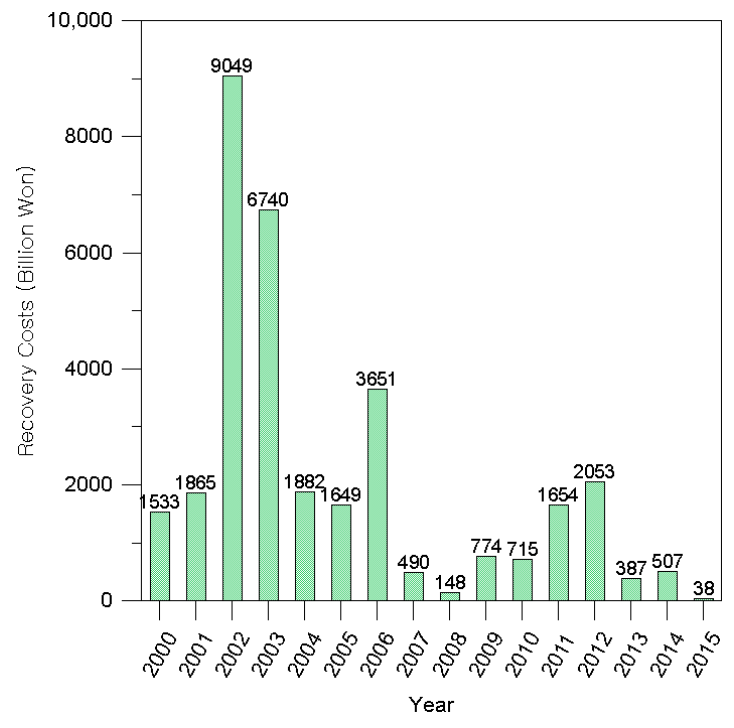

(a)

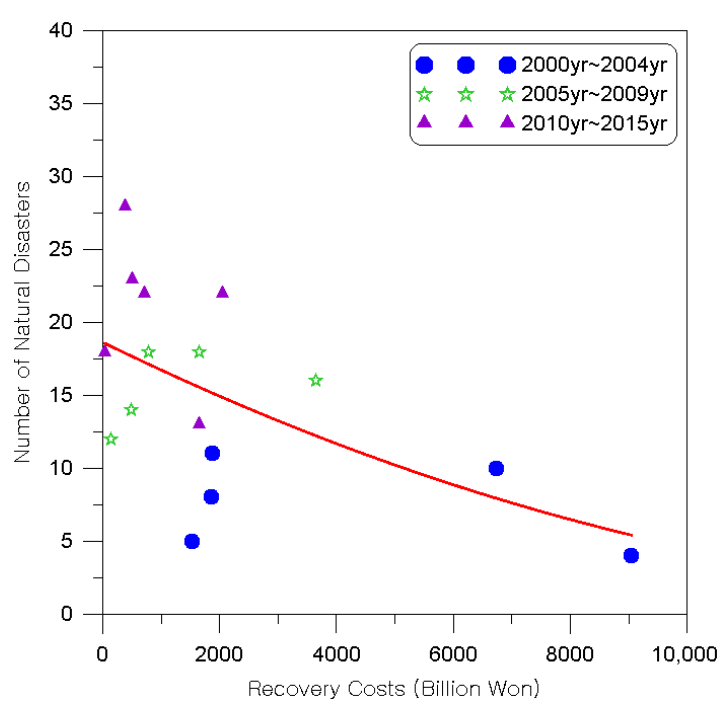

(b)

Figure 5. Current status of recovery costs from natural disasters in the Republic of Korea (2000-2015): (a) Recovery costs from natural disasters by year; (b) Relationship of recovery costs on the number of natural disasters by year.

Damage costs from 2000 to 2015 amounted to 33.134 trillion won and the percentages of recovery costs by year were more than $20 \%$ in 2002 and 2003 , and $5 \%-10 \%$ in $2001,2004,2005,2006,2011$, and 2012. In addition, damage costs of less than $5 \%$ were found in 2000, 2007, 2008, 2009, 2010, 2013, 
2014, and 2015 (Table 4). Regarding recovery costs according to natural disasters, typhoon accounted for $53 \%$, amounting to 17.984 trillion won, heavy rainfall accounted for nearly $36 \%$, amounting to 12.341 trillion won, heavy snowfall accounted for nearly $8 \%$, amounting to 2.729 trillion won, extreme wind accounted for approximately $1 \%$, amounting to 45 billion won, and wind waves accounted for nearly $1 \%$, amounting to 35 billion won. This indicated that typhoon and heavy rainfall generated the highest recovery costs. The annual recovery costs caused by natural disasters occur in the form of an M-shaped increase and decrease with a period of about five years.

Recovery costs caused by typhoon accounted for nearly $87 \%$, amounting to 15.598 trillion won of total damage costs in 2002, 2003, and 2012, from 18.7 billion won to 61.8 billion won in 2004, 2005, 2007, 2010, and 2011, and from 10 billion to 28 billion were generated in 2006, 2008, 2013, 2014, and 2015. Recovery costs caused by heavy rainfall accounted for nearly $62 \%$, amounting to 7.673 trillion won in 2000, 2002, 2006, and 2011; from 331 billion won to 895 billion won were generated in 2001, 2003, 2004, 2005, 2009, 2010, 2013, and 2014; and from 2 billion to 145 billion won were generated in 2007, 2008,2012 , and 2015. Recovery costs caused by heavy snowfall accounted for nearly $96 \%$, amounting to 2.613 trillion won of total damage costs in 2001, 2004, and 2005, and from 1 billion won to 31 billion won were generated during 2006-2015. Recovery costs caused by extreme wind accounted for nearly $80 \%$, amounting to 36 billion won of total damage costs in 2005, 2006, and 2012, 1-3 billion won were generated in 2007, 2009, and 2015. Recovery costs caused by wind waves accounted for nearly $94 \%$, amounting to 33 billion won of total damage costs in 2007 and 2009, and 2 billion won were generated in 2006 .

Table 4. Recovery Costs from Natural Disasters by Year and Disaster in the Republic of Korea (2000-2015) [51-66].

\begin{tabular}{|c|c|c|c|c|c|c|c|}
\hline \multicolumn{8}{|c|}{ (Unit: Billion Won) } \\
\hline Year & Extreme Wind & Heavy Snowfall & Typhoon & Wind Wave & Heavy Rainfall & Sum & Ration (\%) \\
\hline 2000 & 0 & 0 & 433 & 0 & 1100 & 1533 & 5 \\
\hline 2001 & 0 & 970 & 0 & 0 & 895 & 1865 & 6 \\
\hline 2002 & 0 & 0 & 7256 & 0 & 1792 & 9049 & 27 \\
\hline 2003 & 0 & 0 & 6409 & 0 & 331 & 6740 & 20 \\
\hline 2004 & 0 & 883 & 618 & 0 & 381 & 1882 & 6 \\
\hline 2005 & 10 & 760 & 260 & 0 & 619 & 1649 & 5 \\
\hline 2006 & 13 & 3 & 16 & 2 & 3618 & 3651 & 11 \\
\hline 2007 & 3 & 3 & 366 & 19 & 99 & 490 & 1 \\
\hline 2008 & 1 & 1 & 1 & 0 & 145 & 148 & 0 \\
\hline 2009 & 2 & 5 & 0 & 14 & 752 & 774 & 2 \\
\hline 2010 & 0 & 26 & 187 & 0 & 503 & 715 & 2 \\
\hline 2011 & 0 & 30 & 462 & 0 & 1163 & 1654 & 5 \\
\hline 2012 & 13 & 9 & 1933 & 0 & 99 & 2053 & 6 \\
\hline 2013 & 0 & 4 & 4 & 0 & 378 & 387 & 1 \\
\hline 2014 & 0 & 31 & 10 & 0 & 466 & 507 & 2 \\
\hline 2015 & 3 & 5 & 28 & 0 & 2 & 38 & 0 \\
\hline Sum & 45 & 2729 & 17,984 & 35 & 12,341 & 33,134 & 100 \\
\hline Average & 3 & 171 & 1124 & 2 & 771 & 2071 & 6 \\
\hline Min & 0 & 0 & 0 & 0 & 2 & 38 & 0 \\
\hline $\operatorname{Max}$ & 13 & 970 & 7256 & 19 & 3618 & 9049 & 27 \\
\hline
\end{tabular}

\section{Methodology}

\subsection{Analysis of Association between Human Losses and Damage Costs}

In the Republic of Korea, the number of human losses due to natural disasters decreased on average from 2000 to 2015 and the damage costs amounted to 19.947 trillion won. Human losses derived from natural disasters have occurred for 15 years from 2000 and 2014, except for 2015, and damage costs have been generated for 16 years from 2000 to 2015. A linear regression equation was calculated by setting the $\mathrm{X}$ axis as human losses and setting the $\mathrm{Y}$ axis as damage costs in order to analyze the relationship between human losses and damage costs from natural disasters by year (Figure 6). The estimation equation that calculates damage costs considering human losses from 
natural disasters in the Republic of Korea is defined as $Y=22.6 \times X+68.3$ and the coefficient of determination was found to be 0.898 .

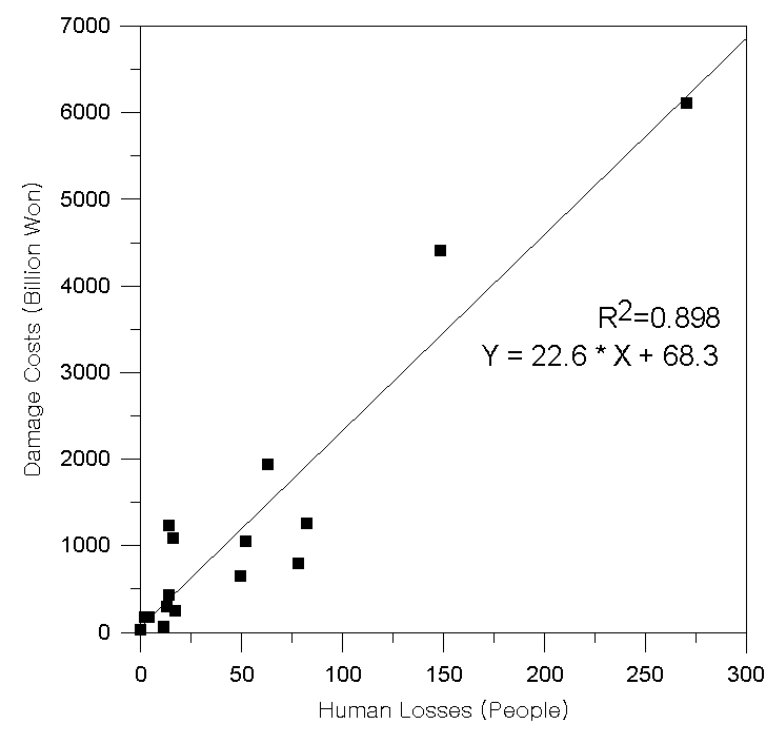

Figure 6. Human losses and damage costs from natural disasters.

Table 5 shows damage costs by year calculated using the estimation equation. MAPE (Mean Absolute Percentage Error) was calculated to examine the prediction accuracy of the estimation equation of damage costs. MAPE of damage costs calculated using the estimation equation by year turned out to be $70 \%$ on average, ranging between $1 \%$ and $395 \%$.

The first reason for the occurrence of errors calculated by the estimation equation compared to damage costs is that damage costs vary even when the same number of human losses occurred due to natural disasters. Second, although damage costs rise when the number of human losses multiply in the case of disasters, human losses do not correspond to damage costs in all natural disasters, and they depend on disaster management strategies such as prevention, preparation, and response. For instance, in 2008, 11 human losses occurred and 64 billion won were estimated as damages, while 13 human losses occurred in 2009, which added two casualties. However, the damage costs amounted to 299 billion won, which was nearly 4.7 times larger than the previous year.

Table 5. Damage Costs by Year and Errors of Damage Costs Calculated by Estimation Equation.

\begin{tabular}{cccc}
\hline Year & Damage Costs (Billion Won) & Calculated Damage Costs (Billion Won) & MAPE (\%) \\
\hline 2000 & 645 & 1176 & 82 \\
2001 & 1256 & 1922 & 53 \\
2002 & 6115 & 6170 & 1 \\
2003 & 4408 & 3413 & 23 \\
2004 & 1231 & 385 & 69 \\
2005 & 1041 & 1244 & 20 \\
2006 & 1943 & 1492 & 23 \\
2007 & 252 & 453 & 80 \\
2008 & 64 & 317 & 395 \\
2009 & 299 & 362 & 21 \\
2010 & 427 & 385 & 10 \\
2011 & 794 & 1831 & 131 \\
2012 & 1089 & 430 & 61 \\
2013 & 172 & 159 & 8 \\
2014 & 180 & 114 & 37 \\
2015 & 32 & 68 & 113 \\
\hline
\end{tabular}

Note: 1 billion won $=\$ 0.930$ million . 


\subsection{Analysis of Correlation between Human Losses and Recovery Costs}

The method used to calculate recovery costs by considering human losses was identical to what was explained in Section 4.1. Eight hundred thirty-three human losses occurred and 33.135 trillion won was calculated for recovery costs on natural disasters from 2000 to 2015. A linear regression equation was calculated by setting the $\mathrm{X}$ axis as human losses, and the $\mathrm{Y}$ axis as recovery costs in order to analyze the relationship between human losses and recovery costs from natural disasters by year (Figure 7). The estimation equation that calculates recovery costs considering human losses from natural disasters in the Republic of Korea is defined as $Z=33.3 \times X+339.1$ and the coefficient of determination was found to be 0.889 .

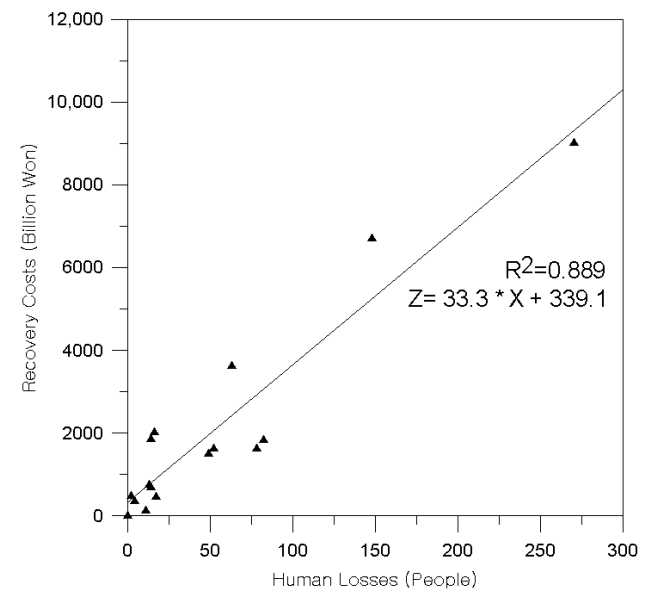

Figure 7. Human losses and recovery costs from natural disasters.

Table 6 exhibits recovery costs according to past years and recovery costs calculated using the estimation equation. MAPE was calculated to examine the prediction accuracy of the estimation equation of the recovery costs. MAPE of recovery costs calculated by the estimation equation was $105 \%$ on average, ranging between $-0 \%$ and $792 \%$, compared to the recovery costs of the past years.

The reason why these errors occur is identical to what is explained in Section 4.1. For example, the annual mean error of damage costs calculated by the equation turned out to be $37 \%$, which reduced the extent, except for in 2008, when the recovery costs were relatively less than human losses, except for in 2015 when no human losses occurred.

Table 6. Errors of Recovery Costs by Year and Recovery Costs Calculated from Estimation Equation.

\begin{tabular}{cccc}
\hline Year & Damage Costs (Billion Won) & Calculated Damage Costs (Billion Won) & MAPE (\%) \\
\hline 2000 & 1533 & 1971 & 29 \\
2001 & 1865 & 3070 & 65 \\
2002 & 9049 & 9330 & 3 \\
2003 & 6740 & 5268 & 22 \\
2004 & 1882 & 805 & 57 \\
2005 & 1649 & 2071 & 26 \\
2006 & 3651 & 2437 & 33 \\
2007 & 490 & 905 & 85 \\
2008 & 148 & 705 & 376 \\
2009 & 774 & 772 & 0 \\
2010 & 715 & 805 & 13 \\
2011 & 1654 & 2937 & 78 \\
2012 & 2053 & 872 & 58 \\
2013 & 387 & 472 & 22 \\
2014 & 507 & 406 & 20 \\
2015 & 38 & 339 & 792 \\
\hline
\end{tabular}

Note: 1 billion won $=\$ 0.930$ million 


\subsection{Analysis of Correlation between Damage Costs and Recovery Costs}

This study analyzed the correlation among human losses, damage costs, and recovery costs due to natural disasters in the Republic of Korea. In Section 4.1, an estimation equation on human losses and damage costs was proposed, and an equation on human losses and recovery costs was presented in Section 4.2. Recovery costs were $166 \%$ higher on average, ranging between at least $119 \%$ and $259 \%$ greater than damage costs every year, as shown in the association between damage costs and recovery costs from 2000 to 2015 (Table 7).

In addition, the results of the estimation equation in Sections 4.1 and 4.2 were analyzed to be similar to the relationship between damage costs and recovery costs in the Republic of Korea. In the Republic of Korea, damage costs amounted to 19,947 billion won and recovery costs was 33,134 billion won, which is $166 \%$ more than the damage costs from 2000 to 2015 . The results of estimation equation of recovery costs and damage costs are presented as same as the past damage status. Therefore, it is assumed that either applying the equation of recovery costs on human losses or calculating the recovery costs to be $166 \%$ higher than the damage costs would be applicable.

Table 7. Damage Costs of Past Natural Disasters and Error of Recovery Costs.

\begin{tabular}{cccccccc}
\hline Year & $\begin{array}{c}\text { Damage } \\
\text { Costs } \\
\text { (billion } \\
\text { won) (1) }\end{array}$ & $\begin{array}{c}\text { Recovery } \\
\text { Costs } \\
\text { (billion } \\
\text { won) (2) }\end{array}$ & $\begin{array}{c}\text { Variation } \\
\text { (\%) (2)/(1) }\end{array}$ & Year & $\begin{array}{c}\text { Damage } \\
\text { Costs } \\
\text { (billion } \\
\text { won) (1) }\end{array}$ & $\begin{array}{c}\text { Recovery } \\
\text { Costs } \\
\text { (billion } \\
\text { won) (2) }\end{array}$ & $\begin{array}{c}\text { Variation } \\
\text { (\%) (2)/(1) }\end{array}$ \\
\hline 2000 & 645 & 1533 & $238 \%$ & 2009 & 299 & 774 & $259 \%$ \\
2001 & 1256 & 1865 & $148 \%$ & 2010 & 427 & 715 & $167 \%$ \\
2002 & 6115 & 9049 & $148 \%$ & 2011 & 794 & 1654 & $208 \%$ \\
2003 & 4408 & 6740 & $153 \%$ & 2012 & 1089 & 2053 & $189 \%$ \\
2004 & 1231 & 1882 & $153 \%$ & 2013 & 172 & 387 & $225 \%$ \\
2005 & 1041 & 1649 & $158 \%$ & 2014 & 180 & 507 & $282 \%$ \\
2006 & 1943 & 3651 & $188 \%$ & 2015 & 32 & 38 & $119 \%$ \\
2007 & 252 & 490 & $194 \%$ & Average & 19,948 & 33,135 & $166 \%$ \\
2008 & 64 & 148 & $231 \%$ & & & & \\
\hline
\end{tabular}

Note: 1 billion won $=\$ 0.930$ million.

\section{Results and Discussion}

The estimation equation proposed in this study is an equation for estimating damage costs and recovery costs based on human losses caused by natural disasters. The estimation equation of damage costs and the recovery costs are calculated by using the linear regression equation for human losses on the $\mathrm{X}$ axis and the damage costs and recovery costs on the $\mathrm{Y}$ axis for the past 15 years in the Republic of Korea. The correlation between damage costs and recovery costs is highly correlated. The MAPE of the damage costs calculated by the equation was $70 \%$ on average compared to the damage costs in the past years considering human losses. The MAPE of the recovery costs calculated by the equation was $105 \%$ on average compared to recovery costs in the past years.

The first reason for the occurrence of errors in the estimation equation of damage costs and recovery costs is that damage costs and recovery costs are different even when the same numbers of human losses occurred in the case of natural disasters. Second, although most damage costs rise when a number of human losses multiply in the case of disasters, the relationship between human losses \& damage costs and human losses \& recovery costs is not proportionate depending on the type of disaster management, such as prevention, preparation, and response to natural disasters.

In a previous study, the estimation of damage costs and recovery costs by year in typhoon, heavy rain, and coast were calculated [14-18]. Disaster management to mitigate natural disasters was conducted to assess the damage compensation equation of the insurance company and vulnerability assessments $[45-47,49,50]$. However, the previous study did not use the direct damages status as a parameter, as it is an estimation equation considering damage costs and damage scale by disaster type. 
Of course, it is difficult to predict natural disasters in other countries as well as in the Republic of Korea. The governments of other countries as well as in the Republic of Korea are more important than the damage of the human losses caused by the disaster. Therefore, in the Republic of Korea, human losses are the first priority to be identified when natural disasters occur. Then, when the damage from natural disasters is completed, the damage costs to land, buildings, and public facilities are calculated. Finally, recovery costs are calculated after consultation between local government and central government based damage costs.

In case of a natural disaster, it is essential to secure a budget in order to execute damage costs and recovery costs. However, it is difficult to predict the magnitude or extent of the damage. Therefore, the results of this study are intended to be used as statistical data to predict the estimated damage costs and recovery costs in the event of natural disasters in the Republic of Korea.

\section{Conclusions}

This study investigated the current status of damage from natural disasters in the Republic of Korea from 2000 to 2015 and proposed an estimation equation on damage costs and recovery costs by considering human losses. The Republic of Korea annually presents the current status of natural disasters and damage such as human losses, damage costs, and recovery costs among metropolitan areas, city and countries, and basin through the Disaster Year Book.

Two hundred forty-two natural disasters occurred from 2000 to 2015. On average, 15 disasters occurred every year in the Republic of Korea. Since the 2000s, the number of natural disasters progressively increased, and the rise and fall of the occurrence of natural disasters repeated on a nearly five-year cycle. Eight hundred thirty-three human losses occurred from 2000 to 2014, with none in 2015 , and the association of human losses on the number of natural disasters showed that an average of four human losses occurred per natural disaster. The association of damage costs on the number of natural disasters showed that 19.947 trillion costs were generated over the 16 years and 82 billion won on average occurred in a single natural disaster. Regarding the association of recovery costs on the number of natural disasters, 33.134 trillion won were generated over the past 16 years and 137 billion won were generated on average per natural disaster.

An estimation equation was produced for human losses, damage costs, and recovery costs due to natural disasters in the Republic of Korea. The equation on human losses and damage costs was $Y=22.6 \times X+68.3$ and the coefficient was 0.898 . The equation on human losses and recovery costs was $Z=33.3 \times X+339.1$ and the coefficient turned out to be 0.889 . Accordingly, it is assumed that applying the equation of recovery costs on human losses or calculating recovery costs to be $166 \%$ higher than damage costs would be applicable. In addition, in regard to the current status of annual damages of natural disasters in the Republic of Korea, 15 natural disasters occurred, 60 human losses occurred, damage costs amounted to 1.23 trillion won, and recovery costs amounted to 2.055 trillion won. These findings are assumed to be used as basis data for handling disasters in the future in the Republic of Korea.

Author Contributions: Y.S.S. carried out the survey of previous studies and wrote the draft of the manuscript. M.J.P. contributed to the analysis of calculating equation that estimates damage costs and recovery costs considering human losses and helped with the writing of the manuscript. Y.S.S. and M.J.P. put forward the concept of this article, led the development of methodology and helped with the modifying of the manuscript. All authors contributed to write, review, correct in this manuscript.

Funding: This research was funded by [Ministry of the Interior and Safety of Korean government] grant number [MOIS-DP-2015-03].

Acknowledgments: This research was supported by a grant [MOIS-DP-2015-03] through the Disaster and Safety Management Institute funded by Ministry of the Interior and Safety of Korean government.

Conflicts of Interest: The authors declare no conflict of interest. 


\section{References}

1. IPCC. Climate Change 2014: Impacts, Adaptation, and Vulnerability; Fifth Assessment Report(AR5) of the Intergovernmenttal Panel on Climate Change; Cambridge University Press: New York, NY, USA, 2014.

2. Min, S.-K.; Zhang, X.; Zwiers, F.W.; Hegerl, G.C. Human contribution to more-intense precipitation extremes. Nature 2011, 470, 378-381. [CrossRef] [PubMed]

3. Pall, P.; Aina, T.; Stone, D.A.; Stott, P.A.; Nozawa, T.; Hilberts, A.G.J.; Lohmann, D.; Allen, M.R. Anthropogenic greenhouse gas contribution to flood risk in england and wales in autumn 2000. Nature 2011, 470, 382-385. [CrossRef] [PubMed]

4. Miller, S.; Muir-Wood, R.; Boissonnade, A. An Exploration of Trends in Normalized Weather-Related Catastrophe Losses; Diaz, H.F., Murnane, R.J., Eds.; Climate Extremes and Society; Cambridge University Press: Cambridge, UK, 2008; pp. 225-247.

5. Holmes, T.P.; Huggett, R.J.; Westerling, A.L. Statistical analysis of large wildfires. In The economics of Forest Disturbances: Wildfires, Storms, and Invasive Species; Holmes, T.P., Prestemon, J.P., Abt, K.L., Eds.; Springer: Dordrecht, The Netherlands, 2008; pp. 59-77.

6. Newman, M.E.J. Power laws, pareto distributions and zipf's law. Contemp. Phys. 2005, 46, 323-351. [CrossRef]

7. Schoenberg Frederic, P.; Peng, R.; Woods, J. On the distribution of wildfire sizes. Environmetrics 2003, 14, 583-592. [CrossRef]

8. Kahn, M.E. The death toll from natural disasters: The role of income, geography, and institutions. Rev. Econ. Stat. 2005, 87, 271-284. [CrossRef]

9. Toya, H.; Skidmore, M. Economic development and the impacts of natural disasters. Econ. Lett. 2007, 94, 20-25. [CrossRef]

10. Eduardo, C.; Andrew, P.; Oscar, B. Estimating the direct economic damages of the earthquake in haiti* Econ. J. 2010, 120, F298-F312.

11. Eduardo, A.; Cavallo, I.N. The Economics of Natural Disasters: A Survey. Available online: https:// publications.iadb.org/handle/11319/1664 (accessed on 30 August 2018).

12. Gil, Y.C. The Normalization Method of Economic Losses from natural Disasters and Its Analysis Results. Available online: http://eprints.lse.ac.uk/30785/1/_Libfile_repository_Content_Neumayer,\%20E_ Normalizing\%20economic\%20loss\%20from\%20natural\%20disasters_Normalizing\%20economic\%20loss\% 20from\%20natural\%20disasters\%20(LSE\%20RO).pdf (accessed on 30 August 2018).

13. Kwon, S.; Kim, J.; Park, H.; Chung, G. Snow damage estimation of gangwon province damages using regression analysis. J. Korean Soc. Hazard Mitig. 2016, 16, 437-443. [CrossRef]

14. Meyer, V.; Becker, N.; Markantonis, V.; Schwarze, R.; Van Den Bergh, J.; Bouwer, L.M.; Bubeck, P.; Ciavola, P.; Genovese, E.; Green, C.; et al. Review article: Assessing the costs of natural hazards-State of the art and knowledge gaps. Nat. Hazards Earth Syst. Sci. 2013, 13, 1351-1373. [CrossRef]

15. Downton, M.W.; Pielke, R.A. How accurate are disaster loss data? The case of U.S. Flood damage. Nat. Hazards 2005, 35, 211-228. [CrossRef]

16. Gall, M.; Borden, K.A.; Cutter, S.L. When do losses count? Bull. Am. Meteorol. Soc. 2009, 90, 799-810. [CrossRef]

17. Gall, M.; Borden, K.A.; Emrich, C.T.; Cutter, S.L. The unsustainable trend of natural hazard losses in the united states. Sustainability 2011, 3, 2157. [CrossRef]

18. Yu, S.; Kim, S.-W.; Oh, C.-W.; An, H.; Kim, J.-M. Quantitative assessment of disaster resilience: An empirical study on the importance of post-disaster recovery costs. Reliab. Eng. Syst. Saf. 2015, 137, 6-17. [CrossRef]

19. Prahl, B.F.; Rybski, D.; Kropp, J.P.; Burghoff, O.; Held, H. Applying stochastic small-scale damage functions to german winter storms. Geophys. Res. Lett. 2012, 39. [CrossRef]

20. Prahl, B.F.; Rybski, D.; Burghoff, O.; Kropp, J.P. Comparison of storm damage functions and their performance. Nat. Hazards Earth Syst. Sci. 2015, 15, 769-788. [CrossRef]

21. Alice, R.Z.; Jonathan, H.J. Dependence of us hurricane economic loss on maximum wind speed and storm size. Environ. Res. Lett. 2014, 9, 064019.

22. Jeong, S.; Yoon, D. Examining vulnerability factors to natural disasters with a spatial autoregressive model: The case of south korea. Sustainability 2018, 10, 1651. [CrossRef] 
23. Tuhkanen, H.; Boyland, M.; Han, G.; Patel, A.; Johnson, K.; Rosemarin, A.; Lim Mangada, L. A typology framework for trade-offs in development and disaster risk reduction: A case study of typhoon haiyan recovery in tacloban, philippines. Sustainability 2018, 10, 1924. [CrossRef]

24. Camerer, C.F.; Kunreuther, H. Decision processes for low probability events: Policy implications. J. Policy Anal. Manag. 1989, 8, 565-592. [CrossRef]

25. Kunreuther, H. Mitigating disaster losses through insurance. J. Risk Uncertain. 1996, 12, 171-187. [CrossRef]

26. Lee, T.-L.; Chen, C.-H.; Pai, T.-Y.; Wu, R.-S. Development of a meteorological risk map for disaster mitigation and management in the chishan basin, taiwan. Sustainability 2015, 7, 962. [CrossRef]

27. Neumayer, E.; Plümper, T.; Barthel, F. The political economy of natural disaster damage. Glob. Environ. Chang. 2014, 24, 8-19. [CrossRef]

28. Raschky, P.A. Institutions and the losses from natural disasters. Nat. Hazards Earth Syst. Sci. 2008, 8, 627-634. [CrossRef]

29. Anbarci, N.; Escaleras, M.; Register, C.A. Earthquake fatalities: The interaction of nature and political economy. J. Public Econ. 2005, 89, 1907-1933. [CrossRef]

30. Escaleras, M.; Anbarci, N.; Register, C.A. Public sector corruption and major earthquakes: A potentially deadly interaction. Public Choice 2007, 132, 209-230. [CrossRef]

31. Neumayer, E.; Plümper, T. The gendered nature of natural disasters: The impact of catastrophic events on the gender gap in life expectancy, 1981-2002. Ann. Assoc. Am. Geogr. 2007, 97, 551-566. [CrossRef]

32. Plumper, T.; Neumayer, E.; Keefer, P. Earthquake Propensity and the Politics of Mortality Prevention; The World Bank: Washington, DC, USA, 2010.

33. Neumayer, E.; Barthel, F. Normalizing economic loss from natural disasters: A global analysis. Glob. Environm. Chang. 2011, 21, 13-24. [CrossRef]

34. Schumacher, I.; Strobl, E. Economic development and losses due to natural disasters: The role of hazard exposure. Ecol. Econ. 2011, 72, 97-105. [CrossRef]

35. Kousky, C. Informing climate adaptation: A review of the economic costs of natural disasters. Energy Econ. 2014, 46, 576-592. [CrossRef]

36. Benfield, A. Annual Global Climate and Catastrophe Report: Impact Forecasting-2012. Available online: http://thoughtleadership.aonbenfield.com/Documents/20130124_if_annual_global_climate_ catastrophe_report.pdf (accessed on 30 August 2018).

37. Barthel, F.; Neumayer, E. A trend analysis of normalized insured damage from natural disasters. Clim. Chang. 2012, 113, 215-237. [CrossRef]

38. Pielke, R.A., Jr.; Landsea, C.W.; Musulin, R.T.; Downton, M. Evaluation of catastrophe models using a normalized historical record. J. Insur. Regul. 1999, 18, 177-194.

39. Bouwer, L.M. Have disaster losses increased due to anthropogenic climate change? Bull. Am. Meteorol. Soc. 2011, 92, 39-46. [CrossRef]

40. Kron, W.; Steuer, M.; Löw, P.; Wirtz, A. How to deal properly with a natural catastrophe database-Analysis of flood losses. Nat. Hazards Earth Syst. Sci. 2012, 12, 535-550. [CrossRef]

41. Kull, D.; Mechler, R.; Hochrainer-Stigler, S. Probabilistic cost-benefit analysis of disaster risk management in a development context. Disasters 2013, 37, 374-400. [CrossRef] [PubMed]

42. Kenny, C. Disaster risk reduction in developing countries: Costs, benefits and institutions. Disasters 2012, 36, 559-588. [CrossRef] [PubMed]

43. Altay, N.; Prasad, S.; Tata, J. A dynamic model for costing disaster mitigation policies. Disasters 2013, 37, 357-373. [CrossRef] [PubMed]

44. Peng, J.; Shan, X.G.; Gao, Y.; Kesete, Y.; Davidson, R.A.; Nozick, L.K.; Kruse, J. Modeling the integrated roles of insurance and retrofit in managing natural disaster risk: A multi-stakeholder perspective. Nat. Hazards 2014, 74, 1043-1068. [CrossRef]

45. Kesete, Y.; Peng, J.; Gao, Y.; Shan, X.; Davidson, R.A.; Nozick, L.K.; Kruse, J. Modeling insurer-homeowner interactions in managing natural disaster risk. Risk Anal. 2014, 34, 1040-1055. [CrossRef] [PubMed]

46. Shan, X.; Peng, J.; Kesete, Y.; Gao, Y.; Kruse, J.; Davidson, R.A.; Nozick, L.K. Market insurance and self-insurance through retrofit: Analysis of hurricane risk in north carolina. ASCE-ASME J. Risk Uncertain. Eng. Syst. Part A Civ. Eng. 2017, 3, 04016012. [CrossRef]

47. Kantamaneni, K.; Phillips, M.; Thomas, T.; Jenkins, R. Assessing coastal vulnerability: Development of a combined physical and economic index. Ocean Coast. Manag. 2018, 158, 164-175. [CrossRef] 
48. Denner, K.; Phillips, M.R.; Jenkins, R.E.; Thomas, T. A coastal vulnerability and environmental risk assessment of loughor estuary, south wales. Ocean Coast. Manag. 2015, 116, 478-490. [CrossRef]

49. Kantamaneni, K. Counting the cost of coastal vulnerability. Ocean Coast. Manag. 2016, 132, $155-169$. [CrossRef]

50. Kantamaneni, K. Coastal infrastructure vulnerability: An integrated assessment model. Nat. Hazards 2016, 84, 139-154. [CrossRef]

51. Ministry of the Interior and Safety. Disaster Year Book in 2000, 1st ed.; Ministry of the Interior and Safety: Seoul, Korea, 2001; pp. 1-964.

52. Ministry of the Interior and Safety. Disaster Year Book in 2001, 1st ed.; Ministry of the Interior and Safety: Seoul, Korea, 2002; pp. 1-873.

53. Ministry of the Interior and Safety. Disaster Year Book in 2002, 1st ed.; Ministry of the Interior and Safety: Seoul, Korea, 2003; pp. 1-807.

54. Ministry of the Interior and Safety. Disaster Year Book in 2003, 1st ed.; Ministry of the Interior and Safety: Seoul, Korea, 2004; pp. 1-784.

55. Ministry of the Interior and Safety. Disaster Year Book in 2004, 1st ed.; Ministry of the Interior and Safety: Seoul, Korea, 2005; pp. 1-793.

56. Ministry of the Interior and Safety. Disaster Year Book in 2005, 1st ed.; Ministry of the Interior and Safety: Seoul, Korea, 2006; pp. 1-806.

57. Ministry of the Interior and Safety. Disaster year book in 2006, 1st ed.; Ministry of the Interior and Safety: Seoul, Korea, 2007; pp. 1-725.

58. Ministry of the Interior and Safety. Disaster Year Book in 2007, 1st ed.; Ministry of the Interior and Safety: Seoul, Korea, 2008; pp. 1-729.

59. Ministry of the Interior and Safety. Disaster Year Book in 2008, 1st ed.; Ministry of the Interior and Safety: Seoul, Korea, 2009; pp. 1-631.

60. Ministry of the Interior and Safety. Disaster Year Book in 2009, 1st ed.; Ministry of the Interior and Safety: Seoul, Korea, 2010; pp. 1-841.

61. Ministry of the Interior and Safety. Disaster Year Book in 2010, 1st ed.; Ministry of the Interior and Safety: Seoul, Korea, 2011; pp. 1-942.

62. Ministry of the Interior and Safety. Disaster Year Book in 2011, 1st ed.; Ministry of the Interior and Safety: Seoul, Korea, 2012; pp. 1-973.

63. Ministry of the Interior and Safety. Disaster Year Book in 2012, 1st ed.; Ministry of the Interior and Safety: Seoul, Korea, 2013; pp. 1-1285.

64. Ministry of the Interior and Safety. Disaster Year Book in 2013, 1st ed.; Ministry of the Interior and Safety: Seoul, Korea, 2014; pp. 1-680.

65. Ministry of the Interior and Safety. Disaster Year Book in 2014, 1st ed.; Ministry of the Interior and Safety: Seoul, Korea, 2015; pp. 1-722.

66. Ministry of the Interior and Safety. Disaster Year Book in 2015, 1st ed.; Ministry of the Interior and Safety: Seoul, Korea, 2016; pp. 1-222.

(C) 2018 by the authors. Licensee MDPI, Basel, Switzerland. This article is an open access article distributed under the terms and conditions of the Creative Commons Attribution (CC BY) license (http://creativecommons.org/licenses/by/4.0/). 